\title{
Investigating Identity, Ambivalence, Hybridity: A Bhabhaian Reading of J. M. Coetzee's Foe and Disgrace
}

\author{
Jalal Mostafaee \\ Islamic Azad University of Baneh Branch, Iran \\ E-mail: Jalal_4pk@yahoo.com
}

Doi:10.7575/aiac.alls.v.7n.6p.163

Received: 02/09/2016

URL: http://dx.doi.org/10.7575/aiac.alls.v.7n.6p.163

Accepted: 06/11/2016

\begin{abstract}
The present paper seeks to investigate J.M. Coetzee's Foe and Disgrace in terms of Homi K. Bhabha's concept of Identities/Subjectivities. Homi K. Bhabha is one of the most important contemporary figure in postcolonial studies; he argues that ambivalence is existed at the site of colonial dominance. He argues that ambivalence is existed at the site of colonial dominance. The colonizer forcefully asserts his superiority to the colonized, but the feeling of fear is created concerning identity, which is imposed on them. The paper also seeks on the notion of hybridity which indicates that the practices of colonial authority is intermingling other texts and discourses which results in a hybridization that facilitates colonial domination. Bhabha's reading of Lacan accords well with the ambivalence he traces in various writers. It is what Lacan calls the mirror stage that is central to Bhabha's reading. Bhabha believes that "the mirror stage encapsulates what happens in colonial discourse's stereotyping productions: the mirror stage is at least a good model for the colonial situation". Bhabha suggests that like" the mirror phase the fullness of the stereotype its image as identity_ is always threatened by lack." A telling and recurring idea in Coetzee's fiction is that the force of the colonizer is formative of the identity of the colonized, something to be embraced and this paper aims to investigate this closely by using Bhabha's concepts.
\end{abstract}

Keywords: Ambivalence, Apartheid, Colonial discourse, Hybridity, Marginality, Mimicry, Stereotype, Uncanny 1. General Overview

John Maxwell 'J. M.Coetzee" has been considered as one of the most highly reverend contemporary authors. His novels have made him a special place in South African literature. His fame was gained after the extraordinary success with Waiting for the Barbarians ${ }^{1}(1980)$ and $F_{o e}{ }^{2}(1986)$. Coetzee acquired a position in a very particular branch of postcolonial writing: the literature of the 'postcolonizer'. His works represent the way of dealing with post-apartheid South Africa. . Bhabha's work develops concepts that are highly significant such as ambivalence, hybridity and mimicry. These concepts accentuates how colonized peoples have resisted the power of the colonizer.

\section{Statement of the Problem}

The present dissertation seeks to critically investigate J.M.Coetzee's Disgrace and Foe in terms of Homi Bhabha's concept of Identities. Disgrace is analyzed in the context of a post-apartheid society in search of its identity. The story of a reticent Lurie, who is divorced twice .He is the professor of modern languages in Cape Technical University. The tragic events on Lurie and his daughter evince the colonial situation and the struggle of power between Negroes and Whites and the matter of their identity. The novel shows the struggle of dominant groups to deal with a changing world in an apartheid-free South Africa. It also shows the colonized peoples suffering from dishonor and unfair treatment. Coetzee has shown comprehensively the failure in Lurie's identity. Lurie is reluctant to change his world Because of South Africa's history of racial oppression and discrimination. So he refuses to give a confession, just as Chapman ${ }^{3}$ said: "The white are endowed with a special racial identity."

Colonialist policies has close affinity with the white's dominance. Therefore, Lurie could not repel the shadow of the dominant colonialists and separate it from his life in colonial time. Dealing with changing world in an apartheid-free South Africa is a hard task. Lurie's identity depends on Colonists' power. As one goes away, the other one disappears too. He feels detached, baffled and defenseless, like a sleepwalker in darkness. The colonialist policies cause wound both for the black and for the white in post-apartheid South Africa. When the white's language disappears the language function disappears too. Lurie suffers from a physical and psychological disability and this is intensified when his daughter is violently raped. This indicates the downfall of the western civilization and identity.

\footnotetext{
${ }^{1}$ It was first published in 1980 .

${ }^{2}$ It is focused mainly on themes of language and power. The novel was the subject of criticism in South Africa, where it was considered to be politically irrelevant

${ }^{3}$ Chapman, Michael 1945
} 
Disgrace is a story of transformation of identity which becomes ambiguous and renders the feeling of ambivalence. On one side they have the dominance over the blacks but on the other hand they hate it. Lucy is the victim of colonialist policies. Her parents' divorce and her homosexual inclination cause her to banish herself to the countryside and separate herself from the rest of the society. When colonialist policies disappear, the colonial evil would spread. The identity shapes itself to be sign of vengeance and a historical abhorrence between different races. Thus, the punishment and atonement of colonial guilt has affected both sides.

Disgrace describes the characters' psychology and attitude throughout the novel. The Cultural identity crisis caused by colonialism is the matter of significance. It focuses on white cultural identity crisis by analyzing the protagonist Lurie's ethics, his languages and his social identity's transformation. Because the Colonialism and apartheid have been smashed, the cultural identity crisis exists a shadow between the black and the white. The only way to resolve the crisis is the cooperation and coexistence between the two races.

The novel is exclusive in the reflection of identity impacted by racism. Racial suppression made the victims too disappoint to show their strong reaction. Thus, they act in the form of revolt affecting the powerful dominating clan of which of Lurie and his daughter are representatives. In cultural identity crisis victims are often denied of their rightful claims. Therefore, Lurie's daughter decides to fight against injustice.

Foe primarily concentrates on themes of power and language and identity,. Coetzee's central themes throughout Foe "'linkage of language and power, the idea that those without voices cease to signify, figuratively and literally". Barton, the main character intends to narrate her own story. She lacks an appropriate language. The agent she chooses to communicate insists in erasing her history. As the story continues Barton loses her identity and sense of history.

Barton is attempting to give voice and identity to Friday who is reticent. The principle significance of the novel is the necessity to give voice and identity to the oppressed. Denis Donoghue ${ }^{4}$ stated that "the political parable [of the novel] issues from Friday's tonguelessness"' Barton observes Friday as speechless which prevents him from gaining his identity. She believes that believes that Friday could overcome his speechlessness and gain his identity by learning to write. Thus, language is a significant factor in the matter of identity crisis.

Friday's identity is remains unacknowledged and pushed into the margin. Susan accuses Cruso of lack of communication between him and Friday. Cruso is not considered as brutal oppressor but is indifferent towards Friday's identity and history. Susan intends to help Friday to regain his identity. She fights for a representation of Friday because she thinks that a true rendition of life on the island is not possible without giving voice to Friday.

\section{Ambivalence, mimicry and hybridity}

According to Bhabha the problem for colonial discourse is that it wants to create submissive subjects to 'mimic' 5 the colonizer. Bhabha argues colonial discourse ${ }^{6}$ is forced to be ambivalent ${ }^{7}$ and this is too threatening. Therefore in postapartheid era the colonizer is both marginalized and encounter the result of the mimicry on the part of the colonized. That is, the colonizer will experience violence, rape, and every kind of revenge on the part of the colonized to compensate for being colonized.

With the fall of apartheid 1994 in South Africa, the world of the white South Africans has been altered enormously. Political and social construction have been reversed. Black South Africans have been empowered over white South Africans. In order to show the identification of the white colonial authority, Bhabha believes that identity forms not from a self-reflection in human nature or a place to show the self in culture and nature, but in a relation to the other. As he states:

[T] he question of identification is never the affirmation of a pregiven identity, never a self-fulfilling prophecy - it is always the production of an image of identity and the transformation of the subject in assuming that image. The demand of identification - that is, to be for an other - entails the representation of the subject in the differentiating order of otherness.

This identity is featured by ambivalence, which includes a process of fright and tendency. The feeling of megalomania and atonement arises in characters so that colonizers feel that they are superior in affinity with the blacks, while at the same time there also exists the feeling of atonement, which pose a threat to colonizers. Thus for maintaining their power and dominance, the colorizers stereotype the black as pejorative, immobile and in the state of chaos.

Disgrace is shown in David Lurie ambivalence. He follows his colonial and Western indulging superiority and stereotypes the blacks negatively. Thus, Coetzee illistrrates a white South African can only bring disgrace. Lurie's idea of white supremacy is reflected in the matter of white cultural superiority. The promiscuity of the protagonist and her daughter indicate a metaphor for the lack of power of white South Africans. The "rape" of Lucy by the three black men on her farm can be considered as subversion of whites supremency

\footnotetext{
${ }^{4}$ Denis Donoghue is an Irish literary critic.

${ }^{5}$ Mimicry

${ }^{6}$ This is a term brought into existence by Edward Said

${ }^{7}$ The complex mix of attraction and repulsion that characterizes the relationship between colonizer and colonized described by Homi Bhabha.
} 
Foe is an ambivalent text in that is a double reading which emphasizes the feminism and post colonialism of the novel. The postcolonial feminism of the novel can be understood by scrutinizing similar predicament of Susan Barton and an African slave called Friday who completes Susan Barton's story just as she completes Robinson Cruso's metafiction narrative and show her resistance and will not allow male dominance to complete her story.

Bhabha borrowed the notion of hybridity from Jacques Derrida ${ }^{8}$. This indicates that the practices of colonial authority is always connecting discourses with other texts. The result is that of deconstructing simple meanings that is: facilitating colonial domination. Thus, the colonizers must change their own way of articulation. Hybridizing the colonial culture and the colonized which shift the colonial power never totally in the hands of the colonizers. Thus, the identity of the colonial authority will be under suspicion.

In Disgrace, Petus's deliberate use of the English language is a good reason. Lurie differentiates his use of the English language and Petrus's, He is not cognizant of the status quo and cannot differentiate between the bad and good, because his colonial ancestors have enrooted the English language in South Africa in order to dominate them. Thus, hybridized English language is created which questions the authority of the English language.

Bhahha illustrates in The Location of Culture ${ }^{9}$ the condition that colonial authority is empowered, and hybridity is just a means to create a complete dominance. Bhabha exemplifies the English Bible and its spread in India. As he states: "'how can the word of God come from the flesh-eating mouths of the English? and - how can it be the European book, when we believe it is God's gift to us?', Therefore, the resistance is produced and authority will be internal. But the changed power has changed whites' engagement in hybridity. Thus, the colonizer and the colonized are on equal footing.

In Foe the identity of unhomeliness is evident and clear-cut which takes the form of loneliness. As Tyson believes, ${ }^{10}$ "Unhomeliness is an emotional state: unhomed people don "et feel at home even in their own homes because they don" $t$ feel at home in any culture and, therefore, don"t feel at home in themselves'. Thus, the feeling of unhomeliness is found in Susan, Friday and Cruso. As Susan says in the novel 'I am becoming an island-dweller. I am forgetting what it is to live on the mainland.". " Susan attempts to show herself as an native settler by emulating the island culture while at the same time communicating with her English heritage

Borbor mentioned on the idea of place in Foe by saying that "She [Susan] has become a settler on the island, and thus, her sense of place and her presentation of the island would be different from those of travelers and explorers embarking on an alien land.' Bhabha believes that this space signifies a resistance to binaries and unitary identities and cultures. Susan describes her feelings: 'In England we will have a roof over our heads that no wind can tear off. But did it not seem to you that the moon of our island was larger than the moon of England, as you remember it, and the stars more numerous?' Susan has received the cultural values of the island life and her imaginations and dreams of Cruso "s Island arouse a feeling of anxiety and no belonging to her homeland and getting stuck between the two worlds.

For Bhabha, mimicry is a technique of colonialism Other to facilitate colonial domination. Mimicry arouses similarity, on the colonized to turn into the colonizer. They always will be positioned differently. Mimicry deconstruct the certainty of colonial dominance and creates an uncertainty in the behavior of the colonized. However, it acts as powerful representation of counter-domination. In The Location of Culture, Homi Bhabbha mentions that a missionary wrote in some remarkable fury:

Still everyone would gladly receive a Bible, and why? That he may store it up as a curiosity; sell it for a few price; or use it for waste paper... Some have been bartered in the markets.... If these remarks are at all warranted then an indiscriminate distribution of the scriptures, to everyone who may say he wants a Bible, can be little less than a waste of time, a waste of money and a waste of expectations. For while the public are hearing of so many Bibles distributed, they expect to hear soon of a correspondent number of conversions

In the above passage, the white missionary makes endeavor to change the religion of the natives into Christianity by forcing them to emulate how to read Bible. But such endeavor failed. The natives received Bible from the whites readily, but they used it for their own purpose that is to exchange for the goods in the market.

Mimicry in Disgrace shows catastrophe of the post-apartheid South Africa which was used by the whites. Those, which used to be the emblem of victory for the whites have been given new interpretation by the black side. Revenge is the result of black mimicry on the whites. The Blacks have accumulated the sense of aversion towards the whites. Pollux in Disgrace cry out at Lurie and her daughter "we will kill you all'. The black's destitution not only end with the white's lack of power but also express their resentful feelings towards the white. Therefore, they subvert the use of colonial strategy and sent it back to their old master. We can conclude that black's mimicry of the Westerners not only emulates English language and farming skills but also white's rape.

Bhabha's reading of Lacan accords well with the ambivalence he traces throughout the various writers. What Lacan calls the mirror stage is central to Bhabha's readings. Bhabha argues ' that the mirror stage encapsulates what happens in colonial discourse's stereotyping productions": the mirror stage is at least a good model for the colonial situation.

\footnotetext{
${ }^{8}$ Jacques Derrida was a French philosopher, born in Algeria. Derrida is best known for developing a form of semiotic analysis known as deconstruction

${ }^{9}$ It is a book by Homi K. Bhabha. He Rethinks questions of identity, social agency and national

${ }^{10}$ Lois Tyson is Professor of English at Grand Valley State University
} 
Bhabha suggests that "Like the mirror phase "the fullness" of the stereotype-its image as identity-is always threatened by lack.' In the mirror stage, egocentrism and hostility are intermingled and for Bhabha this intermingling also characterizes the colonial situation. The egocentrism identified with the metaphoric, and the hostility with the metonymic.

This doubling is a different way of shaping colonial knowledge's ambivalence. It is both an hostile expression of domination over the other and appearance of egocentric anxiety about the self. The colonizer violently impose his superiority to the colonized, but is always anxiously pondering his own identity. Huddart believes that for Bhabha there is "always both an aggressive expression of domination over the other and evidence of narcissistic anxiety about the self."

In Foe the interaction between Susan and Friday can considered as an instance for the relationship between the colonizer and the colonized. Thus, it can be said that Lacan 'concept of the mirror stage" is a principal concept to Bhabhas' notion of colonial discourse ambivalence and also the crisis of identity. The mirror stage expounds the function of stereotyping productions in colonial discourse. McRobbie ${ }^{11}$ believes that for Bhabha "The stereotype produces on the part of the colonizer both power and pleasure and also anxiety and defensiveness". Susan claims her supremacy over Friday as he says "If Friday is not mine to set free, whose is he? No man can be the slave of a dead hand"'.

Asserting superiority over Friday can be interpreted as an attempt on Susan's part in the creation of a stereotype (civilized/uncivilized). Friday has the characteristic of a negative stereotype. Friday is stereotyped as uncivilized/subaltern ${ }^{12}$. He has no name. Durrant ${ }^{13}$ argues that Friday's lack of the name shows that he is uncivilized and uncultivated. According to him, Friday is "the negative image of the Enlightenment subject: a sign of the uncivilized, the inhuman, the native, the infant."

As Ranjbar, R and Farahbakhsh, stated in Bhabha's notion of unhomeliness in J.M.Coetzee's Foe: A postcolonial reading stated that "This stereotype arouse both sense of pleasure and anxiety. If we take a closer look at the relationship of Friday and Susan we can find a great discrepancy in their speech . On one hand Susan challenges her authority and asserts that Friday is not her slave and is a free man: 'Friday was not my slave but Cruso's, and is a free man now. He cannot even be said to be a servant, so idle is his life'" on the other hand, she forcefully brags about her civilization and supremacy over Friday.As Bhabha asserts that these stereotypes create a doubleness-an ambivalencethat simultaneously causes anxiety in the colonizer. Huddart contends, "The colonizer [Susan] aggressively states his superiority to the colonized [Friday], but is always anxiously contemplating his own identity, which is never quite as stable as his aggression implies." Despite the fact that Susan is civilized, she expresses doubt about her own identity which she falls into "'Beckettian doubt.' For Bhabha this ambivalence of colonial relations is something that disturbs the self-identity of the colonizer',

\section{Conclusion}

According to Bhabha the problem for colonial discourse is that it wants to create subjects who make, habits and values - that is, 'mimic' the colonizer. Bhabha argues 'colonial discourse is compelled to be ambivalent because it never really wants colonial subjects to be exact replicas of the colonizers - this would be too threatening". Therefore, the colonizer master sees himself but also not-himself, which is "double vision," such that the master is no longer the Subject but is also the Object, where authority is not supposed to exist. The notion of hybridity which indicates that the practices of colonial authority is intermingling other texts and discourses which results in a hybridization that facilitates colonial domination Bhabha's reading of Lacan accords well with the ambivalence he traces in various writers. It is what Lacan calls the mirror stage that is central to Bhabha's reading. Bhabha believes that "the mirror stage encapsulates what happens in colonial discourse's stereotyping productions: the mirror stage is at least a good model for the colonial situation."’

\section{References}

Bhabha, H.K. (1994). The Location of Culture. London; New York: Routledge.

Borbor T. (2010). Towards a new geographical consciousness: a study of place in the novels of V. S. Naipul and J. M. Coetzee, Ph. D. Thesis University of Sussex..

Chapman, Michael(2006). "Postcolonialism: A Literary Turn.” English in Africa. .

Coetzee, J. M. (2001). Stranger Shores. New York: Penguin Books.

Coetzee, J. M. (1999). Disgrace. London: Secker and Warburg.

Coetzee, J. M. (1992). Doubling the Point: Essays and Interviews. Ed. David Attwell. Cambridge: Harvard University Press.

Coetzee, J. M. (2003). He and His Man

\footnotetext{
${ }^{11}$ Angela McRobbie is a British cultural theorist, feminist

${ }^{12}$ In postcolonial theory, the term subaltern describes the lower classes and the social groups who are at the margins of a society

${ }^{13}$ Sam Durrant is an English lecturer at the University of Leeds.
} 
Donoghue, D. (1987). "Her man Friday". The New York Times.

Durrant, S. (2004). Postcolonial Narrative and the Work of Mourning: J.M. Coetzee, Wilson Harris, and Toni Morrison, State University of New York, Albany, 2 .

Habib M. A. R. (2005).A History of Literary Criticism and Theory: From Plato to the Present, Blackwell, Malden.

Head, D. (2009). The Cambridge Introduction to J. M. Coetzee. Cambridge : Cambridge

University Press.

Huddart, D. (2006). Homi K. Bhabha. London; NewYork: Routledge.

McRobbie, A. (2005). The Uses of Cultural Studies: A Textbook, Sage Publications, London.

McGrath, P. (1994). "To Be Conscious Is to Suffer". New York Times.

Ranjbar, R and Farahbakhsh, A.(2016). Bhabha's notion of unhomeliness in J.M.Coetzee's Foe: A postcolonial reading. Gilan University

Spivak, G. ( 2006 )“Can the Subaltern Speak?” The Post-Colonial Studies Reader.

Ed. Bill Ashcroft et al. London: Routledge,. 28-37.

Tiffin, H. (2006). "Post-Colonial Literatures and Counter-Discourse." The Post-Colonial Studies Reader. 2nd ed. Ed. Bill Ashcroft et al. London: Routledge.

Tyson, L. (2011). Using Critical Theory: How to Read and Write about Literature, Routledge, New York. 